\title{
The Research on the Application of Situational Teaching in College English Teaching
}

\author{
Qiong Mei* \\ Furong College, Hunan University of Arts and Science, Changde, Hunan 415000, China.
}

\begin{abstract}
In order to adapt to the development of the times, College English classroom teaching should also keep pace with the times, and teaching methods need to be constantly reformed and innovated. The application of situational teaching method in College English classroom teaching is to create specific and vivid direct or indirect situations according to different themes in class, so that students can learn English easily and happily in interactive situations. With the rational use of situational teaching method, the students' imagination is enriched, the students' interest in learning English is stimulated, and the students' dominant position in College English class is respected. Through which we guide the students to use multiple senses in English language learning, which reflects the trend of quality education in College English class, and enables students to learn and apply English in the process of teaching in fun.
\end{abstract}

Keywords: Situational Teaching Method; College English Teaching; Application of Teaching

In recent years, as the saying "there is no definite way to teach" goes, more and more teaching methods have been applied in College English teaching. Among them, the application of situational teaching method is an innovation of teaching method. In the way of presentation, teachers create different scenarios according to different teaching themes, reproduce the scenarios through rich and colorful teaching means, and integrate the teaching content with the set scenario themes. Situational teaching can give full play to students' individual thinking, stimulate their interest in English learning, improve their English application ability, and improve their ability to analyze and solve problems. This research mainly discusses the background, advantages and how the situational teaching method is applied in College English teaching.

\section{The background of situational teaching method}

The famous educator Comenius said, "all knowledge begins with the senses"[1]. Students can visualize the abstract things through intuitive perception. Intuitive perception enables students to be on the scene, so as to stimulate their emotions. This teaching method was called situational teaching method in the 1930s-1960s. In the 1960s, the Swiss psychologist Piaget put forward the theory of situational teaching method. Later, the American educationist Bruner and the Soviet educationist Vygotsky made a further constructivist interpretation of this theory, and put forward four elements of situational teaching theory: communication, cooperation, situation and meaning construction.

The language theory of situational English teaching method is mainly based on the theory of British structural linguistics, which holds that language is composed of various elements. Pittman (1963) believes that the principle of English classroom teaching activities is to create a large number of situations for students to practice oral sentence patterns. If you master these structures through practice, you will master the language ${ }^{[2]}$. The difference is that situational English teaching method requires the creation of a situation to practice, which is also a major feature of situational teaching method. Halliday (1964) further developed this theory. He believed that language activities, participants and related elements should be combined to form a real situation. Byrne (1976) pointed out that teachers should guide students to use language like highly skilled conductors ${ }^{[3]}$.

\section{Research achievements of domestic scholars in this field}

\subsection{Research on the application of situational teaching method in College English classroom}

Guo Zongjuan (2014) explored the application of interactive situational teaching method in College English teaching from the practice of College English Teaching in independent colleges. The role of situational teaching method is to cultivate students' language sense, arouse students' learning enthusiasm and improve students' English application ability ${ }^{[4]}$. In view of how to create the scene, this research puts forward the principles of creating the scene, and the key point is the theme and design of the scene. Suggestions in College English Teaching: (1)to create various scenarios for students flexibly; (2)to create direct or indirect scenarios according to the law of thinking development of college students and the characteristics of situational teaching method; (3) to put forward countermeasures in the face of possible problems in interactive situational teaching.

Copyright (C) 2020 Qiong Mei

doi: $10.18282 / 1-e . v 9 i 4.1740$

This is an open-access article distributed under the terms of the Creative Commons Attribution Non-Commercial License (http://creativecommons.org/licenses/by-nc/4.0/), which permits unrestricted non-commercial use, distribution, and reproduction in any medium, provided the original work is properly cited. 
Gong Jian (2017) analyzed the situational teaching mode and its role, and then analyzed its specific application strategies. In College English class, the role of situational teaching lies in: (1)It can stimulate students' imagination and improve their ability to analyze and solve problems. (2)We should respect the dominant position of college students in English classroom teaching, and guide students to use a variety of senses in language learning. (3)To provide students with more opportunities for language practice, and effectively improve college students' English communication ability ${ }^{[5]}$. The application strategies include: to create activity activation situation; to use role-play to build teaching situation; to use debate to build learning situation; to use game and competition to build teaching situation; to use modern media to create teaching situation; to summarize the process of reflection situation teaching.

Li Yonghong (2019) analyzed the problems existing in the current English classroom teaching, and then put forward the specific application strategies of situational teaching method in English Classroom Teaching: (1)Scientific design of problem situations. (2)Introduction of situations related to life. (3)Use of multimedia to create situational models. (4)Setting game situations for students. (5)Analysis of creating situations. ${ }^{[6]}$

\subsection{The application of situational approach in English Teaching}

Wang Zhuorong (2016) and Luo Kunkun (2017) elaborated the basic principles that should be followed in the creation of situational teaching method, including the principle of unity of consciousness and unconsciousness, the principle of unity of intelligence and non-intelligence, the principle of pleasant and easy experience, and the principle of autonomy under mutual trust between teachers and students. The former emphasizes that in situational teaching, students are the main body and the final implementer of the teaching process, and believe that the specific application sequence of the situational teaching method should be situational introduction, situational cognition, situational consolidation, situational application and feedback. The latter thinks that the application of situational teaching in English teaching is reflected in the following aspects: starting from life and creating English teaching situations; using multimedia to create teaching situations; creating students' self-situation; teachers creating teaching situations through various means.

Zhang Lu (2016) introduced the connotation and role of situational teaching method, and believed that situational teaching method can be applied in the following aspects: (1)creating situations in connection with the actual life; (2) using training facilities to create situations; (3) using physical props to create situations; (4)creating situations through modern media ${ }^{[7]}$. Hao Lili (2016) proposed the discomfort of situational teaching method in College English teaching and its remedies. For example, when students refuse to speak for fear of mistakes, they should be encouraged to speak actively and practice; instead of focusing on grammar, they should create situations to stimulate students' interest in learning.

Gu Chunxia (2015) believes that the setting of situations needs to stimulate students' metacognition, find the fit point of students' learning, and enable students to achieve automatic output of knowledge.Wang Xulang (2016) believes that the specific implementation of situational teaching method in English class needs to base on students' current level, and the creation of scenarios needs to be close to students' real life ${ }^{[8]}$.

\subsection{The role and value of situational approach in College English Teaching}

Mu Hongbo (2018) stressed that the core of situational teaching is to arouse students' emotional experience, such as vivid language description, classroom games, role-play, music and painting appreciation, which are all methods to integrate teaching content into specific situations. It is believed that situational teaching can: (1)help teachers to create real situations and make students immersive; (2)help to stimulate students' interest and improve students' participation in class; (3)help students better understand what they have learned; (4)help to inspire students' thinking and cultivate students' independent ability. It also holds that if English teachers want to apply situational teaching method more scientifically, reasonably and effectively, they must have certain knowledge accumulation and professional quality.

Lu Yan (2020) believes that, the application of situational teaching method in College English teaching activities requires the English teachers to design the teaching scene associated with it. According to the content of teaching materials, the students can enhance their participation awareness in teaching activities and enhance their understanding and mastery of English knowledge through experience and practice in this scene.

In addition, based on the situational approach, Jiang Ling (2020) believes that teachers can improve the actual effect of English language and literature teaching only when they attach importance to students' thinking, respect students' learning needs, and regularly improve their teaching innovation ability.

The relevant research results of domestic and foreign scholars not only provide a mature theoretical basis for the research of this topic, but also provide ideas and reference. On basis of the former scholars' research, the author summarizes the advantages and the confusion in the application of situational teaching in College English teaching, and discusses how to use situational teaching to better serve college English teaching.

\section{Advantages of situational teaching method in College English Teaching}

\subsection{Giving full play to the main advantages of college students in English classroom.}

Situational teaching method breaks the traditional English classroom, which takes the teacher's "teaching" as the main body. By creating a situation in line with the teaching theme, it returns the classroom to the students and releases the students' nature. In the situational teaching class, different students are given different roles, so that they can give full play to their individual advantages in teamwork and complete a teaching task together. In this classroom, the teacher is in the position of the instructor, to build a reasonable language situation for students, to provide more opportunities for language practice, to guide students to use a variety of senses for language learning, and fully respect the dominant position of students. 


\subsection{Stimulating the enthusiasm and imagination of college students in learning English.}

Interest is the best teacher in language learning. College students are not satisfied with the traditional classroom indoctrination teaching mode, they hope to participate in classroom activities. They hope they can play a role in the theme classroom activities. Situational teaching can greatly mobilize the enthusiasm of students to participate in the classroom and stimulate their imagination. To set an example, as in the role-play with the theme "what are you going to be after graduation". The students can choose their own roles according to their different professional interests, determine the roles they will play in the team discussion, and then design their own dialogues and narratives in line with the roles, choose reasonable props, and cooperate to complete the whole teaching task. In this process, the enthusiasm and creativity of students are greatly improved, the classroom atmosphere is more active, and the teaching effect is more significant.

\subsection{Using various teaching methods to make college English classroom enjoyable.}

The situational teaching method can adopt a variety of teaching organization forms. For example, using competition mechanism to play English games in groups; singing and appreciating English songs to cultivate language sense; English story Solitaire (story Solitaire based on text understanding); role-play or theme debate based on specific theme; playing English movie to learn oral English expressions; setting questions and creating situation to start a discussion; creating outdoor theme situation to arouse empathy and enlightenment. These teaching organization forms are flexible and interesting, so that students can learn by playing, learning by pleasure and learning by thinking, making learning English so easy and fantastic.

\subsection{Setting and creating the scenarios according to the themes, which helps to improve college students' on-the-spot adapt-}

\section{ability and English application ability.}

In the process of creating and completing the scene theme task, students are required to give full play to their imagination and creativity. For example, in the scenario theme, "as a food segment manager, how to deal with the customer's complaint?" As a member of the team play, the students need to think about how to deal with emergencies such as customer complaints flexibly as a food segment manager. They need to solve problems according to the different needs of customers and the focus of complaints, eliminate customers' doubts, and make feedback that makes customers satisfied. In the process of situational teaching, there is a high demand for students' on-the-spot adaptability. Meanwhile, the students need to be able to adapt to circumstances, use their own wisdom to solve emergencies, and use English way of thinking to organize language expression.

\section{Research methods and results}

This research mainly uses the methods of literature research, questionnaire survey, interview, and case analysis. The data is collected by questionnaire survey (choose 400 English majors and non-English majors as respondents) and interview (choose 20 college English teachers as interviewees). 3-5 specific teaching cases were selected to analyze the advantages and problems of situational teaching method in College English classroom. SPSS system is used for data analysis.

The author mainly research through interviews and questionnaires. Data analysis is carried out using SPSS and other software. Among the 400 questionnaires, 395 copies were returned and 392 were valid. According to the result of the questionnaire, $94.13 \%$ of the respondents confirm that the situational teaching method is utilized in College English classroom. 348 respondents prefer situational teaching method to any other teaching methods, such as lecture (grammar, vocabulary, translation teaching), discussion, drill, task-driven, etc. $84.6 \%$ of the respondents believe that they behave better (more active, more energetic and braver) in the situational teaching classroom.

Among the 20 interviewed teachers, 18 of them confirm that it is common for them to use situational teaching method in College English classroom and it is more popular among the students. Teacher C said, the (situational teaching) classroom is quite active, often the teacher will assign a task and the students will be divided in groups by each responsible for one part. 10 minutes before the class ends, they will perform their achievement in front of the class. Teacher F followed, it (the situational teaching) liberates the classroom, releases the students' nature, and makes the learning full of fun. Even the worst student can try and show here! Teacher H (chief of the English teaching and research section) said, this method (situational teaching method) is most commonly used in College English Viewing, Listening and Speaking curriculum, and is most popularly accepted by the students. Compared to others, in situational teaching classroom, the students can learn more autonomously, and they participate more actively. The teacher plays the role of an instructor, and the class is flexible and effective. Teacher M added, before the lesson, the teacher will make full preparation. For example, a topic or a theme will be chosen for the situational teaching classroom, the arrangement of the whole teaching organization will be prepared. Besides, the application of the situational teaching method in English class should follow certain principles.

\section{Conclusion}

To sum up, the application of situational teaching in College English teaching specifically refers to the fact that, in College English classroom teaching, the teachers set a certain theme subjected to the text materials. They apply a variety of methods to create specific and vivid teaching situation to arouse students' certain attitude experience, and then cultivate students' ability to find, analyze and solve problems. In this way, the students' comprehensive competence is developed and promoted. The application of situational teaching method follows these basic principles: (1)the principle of unity of consciousness and unconsciousness; (2)the principle of unity of intelligence and non-intelligence; (3)the principle of pleasant experience; (4)the principle of mutual trust and mutual emphasis between teachers and students.

The application strategies of situational teaching mainly include: Firstly, the teachers set specific themes according to the teaching content of the text chapters. Secondly, the teachers create situations in line with the theme content according to the theme. 
Thirdly, they use such teaching organization forms as English games, English song appreciation, English story Solitaire, roleplay, theme debate, English movie play, questions setting and situations created to trigger discussion, and create outdoor theme situations, etc. to organize the class and guide the students to study independently and complete the teaching tasks efficiently.

The application of situational teaching in College English teaching can give full play to students' subjective advantages in the classroom and return the classroom to students. Through the students' autonomous learning in the teaching situation and team cooperation to complete the task, the students' enthusiasm and creativity in language learning are stimulated, and their divergent thinking is cultivated. Situational teaching uses a variety of teaching organization forms to make the class teaching in fun, through which it integrates the essence of quality education. The students' practical activities in the theme situation are conducive to improve their ability to solve and deal with problems and develop their English application ability.

In addition, the transformation of "situations" in situational teaching from inside classroom to outside classroom, to come to the real teaching situation, will be a research trend for the author to explore and consider.

\section{References}

[1]Chen Mei. Application of situational approach in College English teaching [J]. Journal of Civil Aviation Flight College of China, 2008; (4).

[2]Davies D, Roberts J, Rossner R. Situational lesson plans [M]. Mexico city: Macmillan, 1975.

[3]Gong Yilin, Chen Zhenzhen, AI Fang. How to create English situational teaching in classroom [J]. Curriculum education research, 2015; (19): 136.

[4]Huo Xiaojing. Research on the application of situational approach in College English teaching [J]. Journal of Inner Mongolia Agricultural University: Social Science Edition, 2010; (4).

[5]Hao Lili. Situational approach and its application in College English Teaching [J]. Journal of Luliang Education Journal, 2016; (4): 66-67.

[6](J)Comenius; trans. Fu Rengan. Magna Didactica [M].Beijing: People's education press, 1984.12: contents page

[7]Xu Yang. Application and thinking of situational teaching method in oral English Teaching [J]. Overseas English, 2011; (8).

[8]Zhou Haiyan. Application of situational teaching method in English Teaching [J]. Learning weekly, 2014; (24). 